\title{
Canopy growth and productivity of Jatropha genotypes
}

\section{Crescimento da copa e produtividade de genótipos de pinhão-manso}

\author{
Joseanny Cardoso da Silva Pereira ${ }^{1 *}$; Adão Wagner Pêgo Evangelista²; Bruno \\ Galvêas Laviola ${ }^{3}$; Tomás de Aquino Portes²; José Alves Júnior²; Derblai Casaroli
}

\begin{abstract}
Information of jatropha genotypes yield are scarce, but necessary to promote the crop establishment, so it is very important for the commercial planting of this crop. Thus, this study aimed to evaluate the canopy growth and productivity of three jatropha genotypes. The experimental design was a randomized block, with 15 treatments, three replications and five plants per plot. The jatropha genotypes were selected because they have some special characteristics: (CNPAE-107 - small size, CNPAE-133 productive and CNPAE-169 - seeds without toxicity) obtained in the Germplasm Bank of Embrapa Agroenergy, Brasília, DF, Brazil. The data were collected for five cycles of production. We evaluated: grain yield; height and canopy volume. Treatments differ in all characteristics. Jatropha grain yield has been growing along the first four years of evaluation, however, in the fifth year production was lower when compared to the fourth year. The most productive genotype was CNPAE-133 (2123.8 $\mathrm{Kg} \mathrm{ha}^{-1}$ year), followed by CNPAE-107 genotypes (2076.5 Kg ha' ${ }^{-1}$ year) and CNPAE-169 (913 Kg ha ${ }^{-1}$ year), the highest yields were obtained at 3.7 years.
\end{abstract}

Key words: Grain yield. Plant growth. Jatropha curcas L.

\section{Resumo}

Informações sobre a produção de genótipos de pinhão-manso por longo período são escassas, mas extremamente necessárias para fomentar o estabelecimento da cultura, assim, é de grande importância realizar pesquisas que testem o desempenho produtivo dessa espécie por longo período de tempo. Dessa forma, objetivou-se avaliar o crescimento da copa e a produtividade de três genótipos de pinhão-manso. O delineamento experimental utilizado foi em blocos ao acaso, constituído de 15 tratamentos, com três repetições e cinco plantas por parcela. Os tratamentos consistiram de genótipos de pinhão-manso selecionados por terem alguma característica especial: (CNPAE-107 - porte baixo, CNPAE-133 produtivo e CNPAE-169 - sementes sem toxicidade) obtidos no banco de germoplasma da Embrapa Agroenergia. Os dados foram coletados durante cinco ciclos de produção. Foram avaliadas: produção de grãos; altura e volume de copa. As plantas diferiram em todas as características avaliadas. A produção de grãos do pinhão-manso foi crescente ao longo dos quatro primeiros anos de avaliação, porém, no quinto ano a produção foi menor quando comparada ao quarto ano. $\mathrm{O}$ genótipo mais produtivo foi o CNPAE-133 (2123,8 $\mathrm{kg} \mathrm{ha}^{-1}$ ano), seguido pelos genótipos CNPAE-107 (2076,5 kg ha' ano) e CNPAE-169 (913 kg ha-1 ano), cujas maiores produtividades foram registradas aos 3,7 anos.

Palavras-chave: Produtividade. Crescimento vegetal. Jatropha curcas L.

${ }^{1}$ Prof $^{a}$ Dr $^{\mathrm{a}}$, Faculdade Evangélica de Goianésia, FACEG, Goianésia, GO, Brasil. E-mail: josycard@yahoo.com.br

2 Profs. Drs., Universidade Federal de Goiás, UFG, Goiânia, GO, Brasil. E-mail: awpego@pq.cnpq.br; portescastro@gmail.com; josealvesufg@yahoo.com.br; derblaicasaroli@yahoo.com.br

${ }_{3}$ Pesquisador Dr., Empresa Brasileira de Pesquisa Agropecuária, EMBRAPA Agroenergia, Brasília, DF, Brasil. E-mail: bruno. laviola@embrapa.br

* Author for correspondence 


\section{Introduction}

Jatropha produces seeds rich in oil (46\% on average) (TRIPATHI et al., 2013), which meets the American and European standards for biodiesel production (TIWARI et al., 2007). It also has desirable characteristics such as drought resistance (KHEIRA; ATA, 2009) and ability to protect the soil against erosion and to assist in the recovery of degraded soils (PARAWIRA, 2010), as occurring in the Brazilian cerrado.

Despite these advantages, the commercial cultivation of jatropha is faced with many obstacles, with the lack of genetically improved cultivars being the most limiting (DURÃES et al., 2009). The identification of accessions with high levels of phenotypic and genetic diversity is the first step in plant breeding (HE et al., 2011). In Brazil, work of this nature have been developed and are extremely important to enable the cultivation of jatropha in the country (JUHÁSZ et al., 2010; LAVIOLA et al., 2011). Among the problems found in plants non domesticated, it has been the presence of toxic components in seeds, the plant high size, which hinders the cultivation and with no cultivars, seed yield is low (DURÃES et al., 2009).

Information on jatropha productivity are numerous, however, most have not been obtained based on scientific studies. Statements and assumptions report that crop yield varies from 2,000 to $5,000 \mathrm{~kg} \mathrm{ha}^{-1}$ and can reach up to 7,800 to 12,000 $\mathrm{kg} \mathrm{ha}^{-1}$. Productivities ranging from $1,250 \mathrm{~kg} \mathrm{ha}^{-1}$ year to $4,500 \mathrm{~kg} \mathrm{ha}^{-1}$ year after the fourth year of cultivation are reported by Owens et al. (2007). According to Openshaw (2000) after five years of growth, seed yield varies from 400 to $12,000 \mathrm{~kg} \mathrm{ha}^{-1}$ year. For the crop establishment, these production reports need to be scientifically proven.

In India, Tripathi et al. (2013) found that the average production of 113 genotypes of jatropha in the second and third year after planting ranged from $26.1 \mathrm{~kg} \mathrm{ha}^{-1}$ to $763.8 \mathrm{~kg} \mathrm{ha}^{-1}$, demonstrating great variability between genotypes and low productivity due to crop is not genetically improved. High yields were obtained by Santoso and Purwoko (2016), in Indonesia, when effect of pruning was tested on jatropha plants. These authors evaluated the production of pine nut for five years and found yield of $8,271.6 \mathrm{~kg} \mathrm{ha}^{-1}$ in the fifth year of cultivation.

Due to the scarcity of information on the production of jatropha genotypes for a long period, and this being extremely necessary to promote crop establishment, it is very important to conduct research that test the productive performance of this species for a long period of time. Thus, this study aimed at evaluating the growth of the crown and the productivity of jatropha genotypes for five production cycles.

\section{Material and Methods}

The experiment was conducted in the experimental area of Centro Nacional de Pesquisa de Agroenergia (CNPAE), in Planaltina, DF, Brazil. The climate is classified as Aw, tropical with dry winter and rainy summer, according to KöppenGeiger. The soil is classified as Oxisol with high clay content. The maximum, minimum and average temperatures are respectively $28.5^{\circ} \mathrm{C}, 17^{\circ} \mathrm{C}$ and $22{ }^{\circ} \mathrm{C}$. The total rainfall in the years of assessment ranged from 1189.2 to $1415.3 \mathrm{~mm}$.

The experimental design was a randomized block with three replications and five plants per plot. Three genotypes of jatropha were evaluated: CNPAE-107 (small size), CNPAE-133 (more productive), and CNPAE-169 (with no toxicity). The evaluations were conducted during five production cycles.

The used genotypes are part of germplasm bank implanted in experimental area of CNPAE. The germplasm bank was established from seed collections of jatropha isolated plants between December 2007 and May 2008 in different regions, collections and plantations of Brazil. A total of 175 genotypes were selected for the development of this research, the CNPAE-107 low size genotypes, 
the productive CNPAE-133 and CNPAE-169 that produces seeds without toxicity. These genotypes are still at characterization phase and initial analysis showed that are divergent for some characteristics of agronomic importance. In general, the three materials were chosen because they have different morphology and agronomic characteristics of commercial interest.

Sowing was performed in tubes of $280 \mathrm{~mL}$, using commercial substrate, with simple superphophate at a dose of $5 \mathrm{~kg} \mathrm{~m}^{-3}$, in discovered nursery. Seedlings were transplanted in November 2008 to planting holes of $0.40 \times 0.40 \times 0.40 \mathrm{~m}, 60$ days after sowing, spaced $4.0 \times 2.0 \mathrm{~m}$. In fertilization it were in each planting hole $300 \mathrm{~g}$ of simple superphophate, 200 $\mathrm{g}$ of limestone and $30 \mathrm{~g}$ of FTE (micronutrients). In topdressing fertilization three applications of 30 $\mathrm{g}$ of NPK (25-0-20 formulation) were performed. In the second year, three applications of $70 \mathrm{~g}$ of NPK (25-0-20 formulation) were performed. From the third year, three applications of $100 \mathrm{~g}$ of NPK (25-0-20 formulation) were performed. Liming has been held annually as soil analysis. The cultivation management as herbicide, fungicide, acaricide application and control of ants were performed as needed.

Fruits were manually harvested in February and March of each year, as it is the time that concentrates the greatest production. Due to the low production in earlier or later months, this was not considered. Thus, it was considered for the calculation of productivity only the fruits harvested in the mentioned months. The productions were presented for each year, with no sum of productions in the five years of assessment. Drying was carried out on ground until seeds reach approximately $12 \%$ of moisture. Then, it was obtained seed mass per plant using a precision balance.

The growth and production of genotypes characteristics were: grain yield (GY) in each year; number of primary branches per plant (NPB), by counting the number of branches in the stem base; plant height (ALT, m), measured by the height between soil and the apex of the plant; canopy projection towards row planting (PCL, m); canopy projection towards inter-row planting (PCE, $\mathrm{m}$ ) and canopy volume $\left(\mathrm{CV}, \mathrm{m}^{3}\right)$. The canopy volume was estimated by approximation of the volume of a cylinder with elliptical base. These evaluations were performed at the end of each rainy season, always in July.

Data were submitted to analysis of variance and treatment means were compared by Tukey test at $5 \%$ probability.

\section{Results and Discussion}

The CNPAE-107 and CNPAE-133 genotypes, during the five crop years, showed the largest mean of grain yield (Table 1). The CNPAE-133 genotype was the most productive, and in relation to plant height and canopy volume, was also the one with the highest means.

Table 1. Average annual of grain yield (GY), number of primary branches (NPB), plant height, canopy projection on the row (CPR), canopy projection on the inter row (CPIR) and canopy volume (CV) of jatropha genotypes CNPAE-107, CNPAE-133 and CNPAE-169 evaluated during 4.7 years in Planaltina, DF.

\begin{tabular}{lcccccc}
\hline Genotypes & $\begin{array}{c}\text { GY } \\
\left(\mathrm{g} \mathrm{plant} \mathrm{p}^{-1}\right)\end{array}$ & NRP & $\begin{array}{c}\text { height } \\
(\mathrm{m})\end{array}$ & $\begin{array}{c}\text { PCL } \\
(\mathrm{m})\end{array}$ & $\begin{array}{c}\text { PCE } \\
(\mathrm{m})\end{array}$ & $\begin{array}{c}\text { VC } \\
\left(\mathrm{m}^{3}\right)\end{array}$ \\
\hline CNPAE-107 & $607.2 \mathrm{a}$ & $15.4 \mathrm{a}$ & $1.9 \mathrm{~b}$ & $1.6 \mathrm{~b}$ & $1.8 \mathrm{~b}$ & $5.1 \mathrm{~b}$ \\
CNPAE-133 & $693.6 \mathrm{a}$ & $9.5 \mathrm{~b}$ & $2.7 \mathrm{a}$ & $1.9 \mathrm{a}$ & $2.3 \mathrm{a}$ & $10.4 \mathrm{a}$ \\
CNPAE-169 & $312.7 \mathrm{~b}$ & $10.4 \mathrm{~b}$ & $1.9 \mathrm{c}$ & $1.5 \mathrm{~b}$ & $1.6 \mathrm{c}$ & $4.6 \mathrm{~b}$ \\
\hline
\end{tabular}

${ }^{*}$ Means followed by the same letter in the column do not differ from each other at $5 \%$ probability by Tukey test. 
It was observed the positive correlation between grain yield and all other variables (Table 2), demonstrating tha all contribute to increase crop production. The highest correlations were observed between grain yield and canopy volume (0.606) and between grain yield and plant height (0.592). Fey et al. (2014) also found a positive correlation between height and production (0.72). As all the features have a positive effect on each other, the improvement of one characteristic will result in improvement of others which the first has positive correlation (GINWAL et al., 2004). Among them, the variable that has more influence on grain production is the canopy projection on inter rows, that also has effect on the canopy volume. These characteristics indicate the efficiency of light interception due to increased distribution of foliage. Thus, these characteristics should be prioritized in breeding programs, since the main problem of jatropha cultivation is low productivity.

Table 2. Correlation between grain yield (GY), number of primary branches (NPB), plant height, canopy projection on the row (CPR), canopy projection on the inter row (CPIR) and canopy volume (CV) of jatropha genotypes CNPAE-107, CNPAE-133 and CNPAE-169 evaluated during 4.7 years in Planaltina, DF.

\begin{tabular}{lcccccc}
\hline & GY $\left(\mathrm{g}\right.$ plant $\left.{ }^{-1}\right)$ & NRP & Height $(\mathrm{m})$ & PCL $(\mathrm{m})$ & PCE $(\mathrm{m})$ & $\mathrm{VC}\left(\mathrm{m}^{3}\right)$ \\
\hline GY & 1 & $0.442^{*}$ & $0.592^{* *}$ & $0.584^{* *}$ & $0.629^{* *}$ & $0.606^{* *}$ \\
NRP & - & 1 & $0.314^{* *}$ & $0.603^{* *}$ & $0.660^{* *}$ & $0.493^{* *}$ \\
Height & - & - & 1 & $0.771^{* *}$ & $0.812^{* *}$ & $0.892^{* *}$ \\
PCL & - & - & - & 1 & $0.963^{* *}$ & $0.930^{* *}$ \\
PCE & - & - & - & - & 1 & $0.939^{* *}$ \\
VC & - & - & - & - & - & 1 \\
\hline
\end{tabular}

${ }^{* *}$ and ${ }^{*}$ significant at 1 and $5 \%$ probability, respectively.

Plant height of genotypes increased over the years, with strong growth at the early of crop cycle (Figure 1). In the third year, all genotypes were pruned in order to facilitate management, and because of that the height growth has stabilized. The greatest growth was observed in CNPAE-133 genotype, which at 52 months reached $3.0 \mathrm{~m}$ in height. In the third year, plant height stabilized in CNPAE-133 and CNPAE-107 genotypes, reaching 2.9 and $2.3 \mathrm{~m}$. It is noteworthy that the vigorous growth of culture is not convenient because this may hamper the implementation of cultural and phytosanitary treatments, and harvesting operation (ACHTEN et al., 2008). The same authors also said that the average height of plants when adults should not exceed two meters, what occurred with the plans of CNPAE-133 genotype, thus, justifying the use of management techniques in this case, as an example, the pruning of plants. The ideal plant height for ease management should range from 1.5 to $2.0 \mathrm{~m}$ (SUNIL et al., 2008). Thus, CNPAE-107 and CNPAE-169 genotypes are within the required standard height (maximum height of $2.2 \mathrm{~m}$ and 2.3 respectively).

When comparing the production of genotypes in the first year, it is observed that the largest increase was obtained by CNPAE-133 genotype (319.3 $\mathrm{kg} \mathrm{ha}^{-1}$ year). In the third and fourth year, CNPAE-133 genotype $\left(2123.9 \mathrm{~kg} \mathrm{ha}^{-1}\right.$ year and $1201.9 \mathrm{~kg} \mathrm{ha}^{-1}$ year, respectively) and CNPAE-107 (1661.2 $\mathrm{g}$ and $788.4 \mathrm{~g}$, respectively) had equivalent productions. In the fifth year, all genotypes reduced their production (CNPAE-107 produced 2076.5 $\mathrm{kg} \mathrm{ha}^{-1}$ in the fourth year and $985.5 \mathrm{~kg} \mathrm{ha}^{-1}$ year in the fifth year, CNPAE-133, $2123.9 \mathrm{~kg} \mathrm{ha}^{-1}$ year and $1201.9 \mathrm{~kg} \mathrm{ha}^{-1}$ year and CNPAE-169, $913.0 \mathrm{~kg}$ $\mathrm{ha}^{-1}$ year and $629.3 \mathrm{~kg} \mathrm{ha}^{-1}$ year, respectively). The highest percentage of reduction was observed in CNPAE-133 genotype, but even so, this genotype was the one that produced more in the fifth year. The 
genotype that showed lower reduction percentage in production was the CNPAE-169, but it was also presented the lowest increase in production over the years. When evaluating the effect of pruning on the production of jatropha plants, Santoso and Purwoko (2016) found that when pruning was performed in the second year, plants reached $8271.6 \mathrm{~kg} \mathrm{ha}^{-1}$ year. These authors observed constant growth in plant production over time.

Figure 1. Plant height of three jatropha genotypes evaluated during 4.7 years in Planaltina, DF.

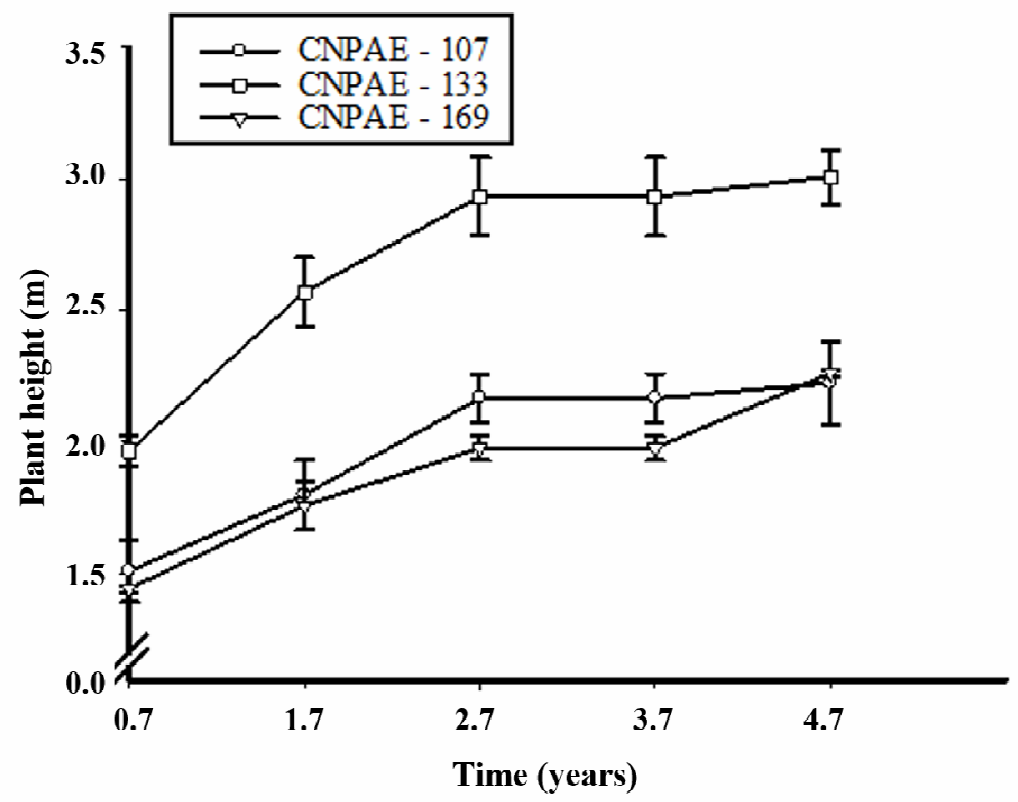

In terms of productivity, the genotype with the highest production over the years was CNPAE 133. At 3.7 years of production, it reached $2123.8 \mathrm{~kg} \mathrm{ha}^{-1}$ and at 4.7 years, it was reduced to $1201.9 \mathrm{~kg} \mathrm{~h}^{-1}$.

In the evaluation of 113 genotypes of jatropha, the maximum production found in the third year after planting by Tripathi et al. (2013) was 783.8 $\mathrm{kg} \mathrm{ha}^{-1}$. In this research, the maximum production in the same year was $570.1 \mathrm{~kg} \mathrm{ha}^{-1}$ per plant. The jatropha potential is much higher, because the evaluated plants are unimproved. Thus, for good yields, it is crucial the improvement of species.

There are few studies on the performance of jatropha genotypes over the years. The maximum assessment time of genotypes was performed with this species was three years (TRIPATHI et al., 2013; PANDEY et al., 2010). This research is the first that evaluates Jatropha genotypes for almost five years. During the first four years of evaluation, all genotypes increased grain production in relation to the previous year, however, from de fourth to the fifth year, all of them reduced its production (Figure 2). This situation was not expected, because according to Pandey et al. (2010), maximum productivity of jatropha grains is obtained from plants with about three to five years old, which was not confirmed in the genotypes evaluated in this study because there was a reduction in the production from the fourth to the fifth year and at last year, grain production per plant did not reach one kilo. 
Figure 2. Grain yield of three jatropha genotypes evaluated during 4.7 years in Planaltina, DF.

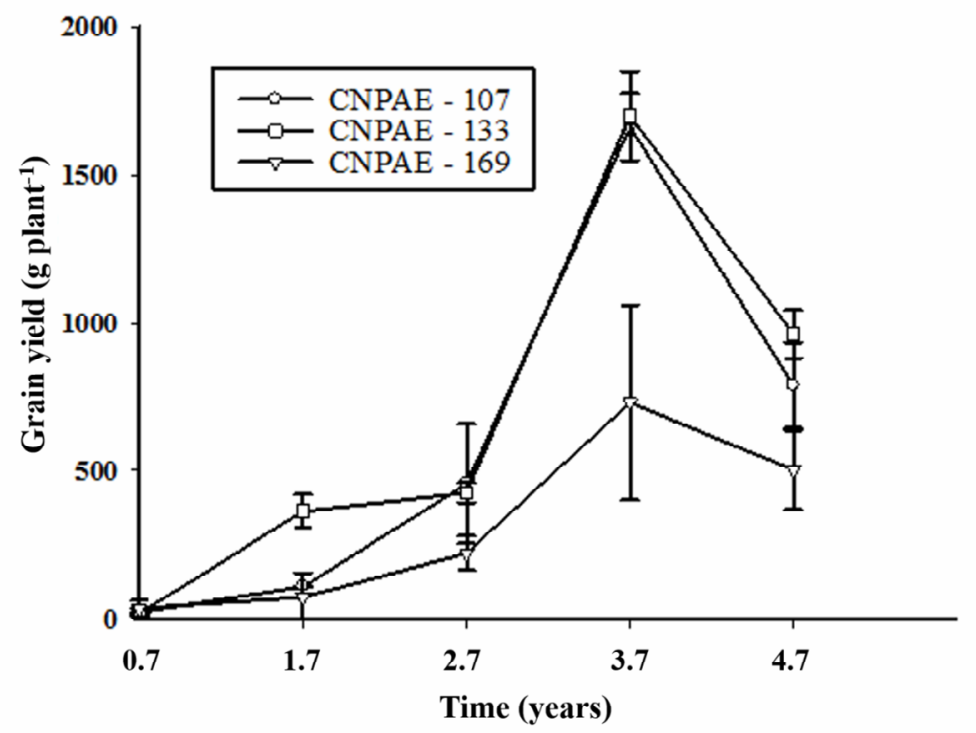

Perennial species such as mango, tangerine, orange, pear, peach, grape, and coffee have alternating production that occurs due to excessive production of fruit in a year, causing depletion of some mineral nutrients and reserve substances, disabling the plant to promote good formation of flower buds and to support the amount of fruit of the following year (FACHINELLO et al., 2008). In this research, as higher production was achieved in the fourth year, may have been depleted reserves due to excessive flowering followed by high production as found by Maia et al. (2010) in tangerine, leading to reduced production in the fifth year.

\section{Conclusions}

There is a positive correlation between the number of primary branches per plant, plant height, canopy projection towards planting row, canopy projection towards planting inter row, canopy volume and grain production.

The most productive genotypes were CNPAE-107 and CNPAE-133, with higher productivity in the fourth year of $2076.5 \mathrm{~kg} \mathrm{ha}^{-1}$ year and $2123.8 \mathrm{~kg} \mathrm{ha}^{-1}$ year respectively.

\section{Acknowledgments}

To Coordenação de Aperfeiçoamento de Pessoal de Nível Superior (CAPES) for financial support, to Embrapa Agroenergia, by availability of the experimental area and infrastructure for conducting research and to Embrapa employees, Júlio Cesar Marana and Laíse Teixeira Costa, for their help in conducting experiment.

\section{References}

ACHTEN, W. M. J.; VERCHOT, L.; FRANKEN, Y. J.; MATHIJS, E.; SINGH, V. P.; AERTS, R.; MUYS, B. Jatropha bio-diesel production and use. Biomass and Bioenergy, Oxford, v. 32, n. 12, p. 1063-1084, 2008.

DURÃES, F. O. M.; LAVIOLA, B. G.; SUNDFELD, E.; MENDONCA, S.; BHERING, L. L. Pesquisa, desenvolvimento e inovação: focando pinhão-manso para como matéria prima para produção de biodiesel. Brasília: EMBRAPA Agroenergia, 2009. 29 p. (Série Documentos, 1).

FACHINELLO, J. C.; NACHTIGAL, J. C.; KERSTEN, E. Poda das plantas frutíferas. In: FACHINELLO, J. C.; NACHTIGAL, J. C.; KERSTEN, E. Fruticultura: fundamentos e práticas. Pelotas: EMBRAPA Clima Temperado, 2008. p. 93-102. 
FEY, R.; MALAVASI, U. C.; MALAVASI, M. M.; SCHULZ, D. G.; DRANSKI, J. A. L. Relações interdimensionais e produtividade de pinhão-manso (Jatropha curcas L.) em sistema silvipastoril. Semina: Ciências Agrárias, Londrina, v. 35, n. 2, p. 613-624, 2014.

GINWAL, H. S.; RAWAT, P. S.; SRIVASTAVA, R. L. Seed source variation in growth performance and oil yield of Jatropha curcas Linn. in Central India. Silvae Genetica, Frankfurt, v. 53, n. 4, p. 186-192, 2004.

HE, W.; KING, A. J.; KHAN, M. A.; CUEVAS, J. A.; RAMIARAMANANA, D.; GRAHAM, I. A. Analysis of seed phorbol-ester and curcin content together with genetic diversity in multiple provenances of Jatropha curcas L. from Madagascar and Mexico. Plant Physiology and Biochemistry, Nova Deli, v. 49, n. 10, p. 1183-1190, 2011.

JUHÁSZ, A. C. P.; MORAIS, D. L. B.; SOARES, B. O.; PIMENTA, S.; RABELLO, H. O.; RESENDE, M. D. V. Parâmetros genéticos e ganho com a seleção para populações de pinhão-manso (Jatropha curcas). Pesquisa Florestal Brasileira, Colombo, v. 30, n. 61, p. 25-35, 2010.

KHEIRA, A.A. A.;ATTA, N. M. M. Response of Jatropha curcas L. to water deficit: Yield, water use efficiency and oilseed characteristics. Biomass and Bioenergy, Oxford, v. 33, n. 10, p. 1343-1350, 2009.

LAVIOLA, B. G.; BHERING, L. L.; MENDONÇA, S.; ROSADO, T. B.; ALBRECHT, J. C. Caracterização morfo-agronômica do banco de germoplasma de pinhãomanso na fase jovem. Bioscience Journal, Uberlândia, v. 27, n. 3, p. 371-379, 2011.

MAIA, E.; SIQUEIRA, D. L.; CECON, P. R. Produção, florescimento e frutificação de tangerineira 'Poncã' submetida à aplicação de ácido giberélico. Ciência Rural, Santa Maria, v. 40, n. 3, p. 507-512, 2010.
OPENSHAW, K. A review of Jatropha curcas: an oil plant of unfulfilled promise. Biomass and Bioenergy, Oxford, v. 19, n. 1, p. 1-15, 2000.

OWENS, K. D.; FRANCIS, G.; FRANKEN, Y. J.; RIJSSENBEEK, W.; RIEDACKER, A.; NIKOLAUS FOIDL, N.; JONGSCHAAP, R.; BINDRABAN, P. Position paper on jatropha and large scale project development. Wageningen: FACT, jun. 2007. 7 p.

PANDEY, A. K.; BHARGAVA, P.; GUPTA, N.; SHARMA, D. Performance of Jatropha curcas: a biofuel crop in wasteland of Madhya Pradesh, India. International Journal of Energy and Environment, Teerã, v. 1, n. 6, p. 1017-1026, 2010.

PARAWIRA, W. Biodiesel production from Jatropha curcas: a review. Scientific Research and Essays, Nairobi, v. 5, n. 14, p. 1796-1808, 2010.

SANTOSO, B. B.; PURWOKO, B. S. Yield performance of Jatropha curcas L. after pruning during five years production cycles in north Lombok Dry Land, Indonesia. Global Advanced Research Journal of Agricultural Science, Belgrado, v. 5, n. 3, p. 103-109, 2016.

SUNIL, N.; VARAPRASAD, K. S.; SIVARAJ, N.; KUMAR, T. S.; ABRAHAM, B.; PRASAD, R. B. N. Assessing Jatropha curcas L. germplasm in-situ - A case study. Biomass and Bioenergy, Oxford, v. 32, n. 3, p. 198-202, 2008.

TIWARI, A. K.; KUMAR, A.; RAHEMAN, H. Biodiesel production from jatropha oil (Jatropha curcas) with high free fatty acids: An optimized process. Biomass and Bioenergy, Oxford, v. 3, n. 8, p. 569-575, 2007.

TRIPATHI, A.; MISHRA, D. K.; SHUKLA, J. K. Genetic variability, heritability and genetic advance of growth and yield components of Jatropha (Jatropha curcas L.) genotypes. Trees, Berlin, v. 27, n. 4, 1049-1060, 2013. 
